\title{
Endozoicomonas montiporae sp. nov., isolated from the encrusting pore coral Montipora aequituberculata
}

\author{
Cho-Song Yang, ${ }^{1}$ Ming-Hui Chen, ${ }^{1}$ A. B. Arun, ${ }^{2}$ Chaolun Allen Chen, ${ }^{3}$ \\ Jih-Terng Wang ${ }^{4}$ and Wen-Ming Chen ${ }^{1}$ \\ ${ }^{1}$ Laboratory of Microbiology, Department of Seafood Science, National Kaohsiung Marine \\ University, 142 Hai-Chuan Road, Nan-Tzu, Kaohsiung City 811, Taiwan \\ ${ }^{2}$ Yenepoya Research Center, Yenepoya University, Nithyananda Nagar, Deralakatee, Mangalore, \\ Karnataka, India \\ ${ }^{3}$ Research Center for Biodiversity, Academia Sinica, Nangang 115, Taipei, Taiwan \\ ${ }^{4}$ Institute of Biotechnology, Tajen University, Yanpu, Pingtung 907, Taiwan
}

Correspondence

Wen-Ming Chen

p62365@ms28.hinet.net

\begin{abstract}
A Gram-negative, aerobic, rod-shaped bacterium, designated strain CL-33 ${ }^{\top}$, was isolated from the encrusting pore coral Montipora aequituberculata collected from seawater off the coast of southern Taiwan. 16S rRNA gene sequence analysis showed that the strain clustered closely with Endozoicomonas elysicola $\mathrm{MKT}_{110^{\top}}$ ( $96.7 \%$ similarity). The novel strain required $\mathrm{NaCl}$ for growth and exhibited optimal growth at $25{ }^{\circ} \mathrm{C}$ and in the presence of $2-3 \% \mathrm{NaCl}$. Predominant cellular fatty acids were summed feature $3\left(\mathrm{C}_{16: 1} \omega 7 c\right.$ and/or $\left.\mathrm{C}_{16: 1} \omega 6 c ; 39.6 \%\right)$, summed feature $8\left(\mathrm{C}_{18: 1} \omega 7 c\right.$ and/or $\left.\mathrm{C}_{18: 1} \omega 6 c ; 32.8 \%\right)$ and $\mathrm{C}_{16: 0}(12.0 \%)$. The DNA $\mathrm{G}+\mathrm{C}$ content of strain CL-33 ${ }^{\top}$ was 50.0 mol\%. The results of physiological and biochemical tests allowed the clear phenotypic differentiation of this isolate from E. elysicola. It is evident from the genotypic, phenotypic and chemotaxonomic data presented that strain CL-33 ${ }^{\top}$ represents a novel species of the genus Endozoicomonas, for which the name Endozoicomonas montiporae sp. nov. is proposed. The type strain is CL-33 ${ }^{\top}$ (=LMG $24815^{\top}=$ BCRC $\left.17933^{\top}\right)$.
\end{abstract}

The genus Endozoicomonas, proposed by Kurahashi \& Yokota (2007), belongs to the order Oceanospirillales of the class Gammaproteobacteria. At the time of writing, the genus comprises only one recognized species, Endozoicomonas elysicola, which was isolated from the sea slug Elysia ornata collected from off the coast of Izu-Miyake Island, Japan (Kurahashi \& Yokota, 2007). The aim of the present study was to determine the taxonomic position of an Endozoicomonas-like bacterium, strain CL-33 ${ }^{\mathrm{T}}$, isolated from the encrusting pore coral Montipora aequituberculata collected from off the coast of southern Taiwan.

A coral sample ( $50 \mathrm{~g}$ ) was collected in a sterile bag from the Kenting coast (Pingtung County, southern Taiwan) at a depth of $10-15 \mathrm{~m}$, stored at $4{ }^{\circ} \mathrm{C}$ and transported to the laboratory within 3-4 h. The coral sample was ground completely and plated on marine agar 2216 (MA; BD Difco) by using the standard dilution plating method. After incubation of the plates at $25{ }^{\circ} \mathrm{C}$ for 5 days, strain CL-33 ${ }^{\mathrm{T}}$ was purified as a single colony. The strain was preserved at $-80{ }^{\circ} \mathrm{C}$ as a $20 \%(\mathrm{v} / \mathrm{v})$ glycerol suspension in marine broth

The GenBank/EMBL/DDBJ accession number for the 16S rRNA gene sequence of strain $C L-33^{\top}$ is $\mathrm{FJ} 347758$.
2216 (MB; BD Difco) or by lyophilization with $20 \%$ (w/v) skimmed milk. Reference strain E. elysicola JCM $21568^{\mathrm{T}}$ was obtained from the Japan Collection of Microorganisms.

Bacterial cells were observed by phase-contrast microscopy (DM 2000; Leica) in the lag, exponential and stationary phases of growth to ascertain their morphology. Cell motility was tested by using the hanging drop method. The Spot Test flagella stain (BD Difco) was used to stain any flagella that might be present. A Gram-stain set (BD Difco) and the Ryu non-staining $\mathrm{KOH}$ method (Powers, 1995) were used to ascertain the Gram reaction. Accumulation of poly- $\beta$-hydroxybutyrate granules was investigated by light microscopy after staining of the cells with Sudan black. Colony morphology was examined by using a stereoscopic microscope (SMZ 800; Nikon). The optimum pH range for growth was examined in $\mathrm{MB}$ by using the following biological buffers: $\mathrm{pH} 3.0-4.0$, glycine/ $\mathrm{HCl}$; $\mathrm{pH} 4.0-8.0$, citrate $/ \mathrm{Na}_{2} \mathrm{HPO}_{4} ; \mathrm{pH} 6.0-8.0$, phosphate buffer; 9.0-11.0, glycine $/ \mathrm{NaOH}$ (at $1.0 \mathrm{pH}$ unit intervals). The $\mathrm{pH}$ was adjusted prior to sterilization and post-sterilization controls revealed only minor changes in $\mathrm{pH}$. Tolerance to various $\mathrm{NaCl}$ concentrations was tested on nutrient broth prepared according to the formula of the BD Difco 
medium, except that the $\mathrm{NaCl}$ concentration was altered as required $(0,0.5$ and $1.0-5.0 \%, \mathrm{w} / \mathrm{v}$, at increments of $1.0 \%)$. Growth at various temperatures $\left(4-45^{\circ} \mathrm{C}\right)$ was measured in $\mathrm{MB}$. Cellular growth was determined by measuring the turbidity $\left(\mathrm{OD}_{600}\right)$ of cultures grown at various $\mathrm{pH}$ values, $\mathrm{NaCl}$ concentrations and temperatures. Anaerobic cultivation was performed on MA by using the Oxoid AnaeroGen system.

Extraction of genomic DNA, PCR amplification and sequencing of the 16S rRNA gene were carried out as described by Chen et al. (2001). The 16S rRNA gene sequence of strain CL-33 ${ }^{\mathrm{T}}$ was obtained by using a DNA sequencer (ABI Prism 310; Applied Biosystems) and was then assembled by using the Fragment Assembly System program from the Wisconsin package (GCG, 1995). An almost-complete $16 \mathrm{~S}$ rRNA gene sequence (1464 nt) of the strain was compared against 16S rRNA gene sequences available from the EzTaxon (Chun et al., 2007), Ribosomal Database Project (Maidak et al., 2001) and GenBank (http://www.ncbi.nlm.nih.gov/BLAST/) databases. Multiple sequence alignment with strain CL- $33^{\mathrm{T}}$ and its closest relatives was performed by using BioEdit software (Hall, 1999) and MEGA, version 3.1 (Kumar et al., 2004). Phylogenetic trees were inferred by using the maximumlikelihood (Felsenstein, 1981), maximum-parsimony (Kluge \& Farris, 1969) and neighbour-joining (Saitou \& Nei, 1987) algorithms. An evolutionary distance matrix was generated for the neighbour-joining algorithm by using the Jukes \& Cantor (1969) distance model; bootstrap analysis for the neighbour-joining tree was performed on the basis of 1000 resamplings. A comparison of the $16 \mathrm{~S}$ rRNA gene sequence of strain CL- $33^{\mathrm{T}}$ with those of members of genera of the order Oceanospirillales in the Gammaproteobacteria showed that the novel strain fell within the evolutionary radiation occupied by the genus Endozoicomonas (Fig. 1). In the phylogenetic tree based on the neighbour-joining algorithm, strain CL- $33^{\mathrm{T}}$ formed a coherent clade with E. elysicola MKT110 ${ }^{\mathrm{T}}$. A similar topology was obtained in phylogenetic trees generated by the maximum-parsimony and maximumlikelihood algorithms (Fig. 1). According to pairwise sequence comparisons, strain CL-33 ${ }^{\mathrm{T}}$ was related most closely to E. elysicola MKT110 ${ }^{\mathrm{T}}$ (96.7\% 16S rRNA gene sequence similarity). Levels of $16 \mathrm{~S}$ rRNA gene sequence similarity between strain CL-33 ${ }^{\mathrm{T}}$ and the type strains of other recognized species within the order Oceanospirillales of the Gammaproteobacteria were below $92 \%$.

The DNA G + C content of strain CL- $33^{\mathrm{T}}$ was estimated as described by Mesbah et al. (1989). The nucleoside mixture was separated by means of HPLC. The DNA G $+\mathrm{C}$ content of strain CL- $33^{\mathrm{T}}$ was $50.0 \pm 1.0 \mathrm{~mol} \%$ (mean $\pm \mathrm{SD}$ of three determinations).

Biomass of strain CL-33 ${ }^{\mathrm{T}}$ and E. elysicola JCM $21568^{\mathrm{T}}$ was obtained after growing the strains on $\mathrm{MA}$ at $25{ }^{\circ} \mathrm{C}$ for 3 days. Fatty acid methyl esters were prepared, separated and identified according to the instructions for the Microbial Identification System (Microbial ID; MIDI Inc.) (Sasser, 1990). The predominant fatty acid constituents of strain CL-33 ${ }^{\mathrm{T}}$ were summed feature $3\left(\mathrm{C}_{16: 1} 107 c\right.$ and/or $\left.\mathrm{C}_{16: 1} \omega 6 c\right)$, summed feature $8\left(\mathrm{C}_{18: 1} \omega 7 \mathrm{c}\right.$ and/or $\mathrm{C}_{18: 1} \omega 6 c$ ) and $\mathrm{C}_{16: 0}$ (Table 1). Isoprenoid quinones were purified by the methods outlined in Minnikin et al. (1984) and were analysed by HPLC as described by Collins (1985). The isoprenoid quinones of strain CL-33 ${ }^{\mathrm{T}}$ were ubiquinone Q-9 (91\%) and Q-8 (5\%).

DNA-DNA hybridization experiments were performed with E. elysicola JCM $21568^{\mathrm{T}}$ by using the methods described by Ezaki et al. (1989). The results indicated low levels of DNA-DNA relatedness between strain CL-33 ${ }^{\mathrm{T}}$ and E. elysicola JCM $21568^{\mathrm{T}}(12.7 \pm 5.7 \%$; reciprocal, $14.5 \pm$ $4.8 \%$ ) (means \pm SD of three determinations). These values are clearly below the $70 \%$ cut-off point recommended

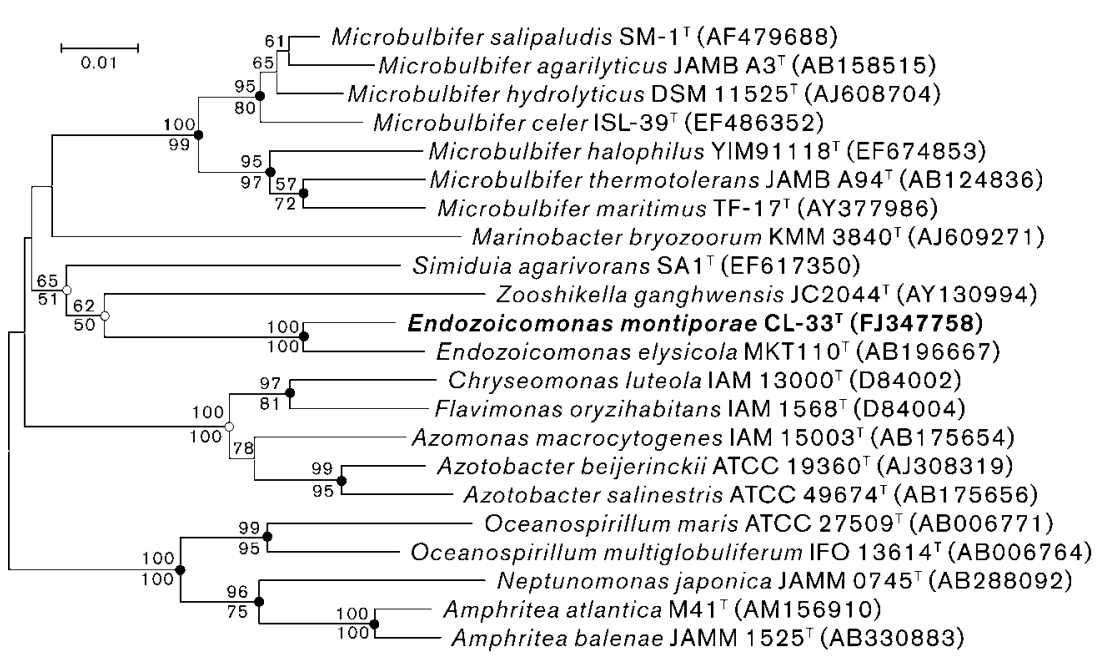

Fig. 1. Phylogenetic tree, based on $16 \mathrm{~S}$ rRNA gene sequences and constructed by using the neighbour-joining algorithm with the distance model of Jukes \& Cantor (1969), showing the phylogenetic position of strain $\mathrm{CL}-33^{\top}$ within the genus Endozoicomonas. GenBank accession numbers are shown in parentheses. Numbers at nodes are bootstrap percentages (of 1000 resampled datasets) based on the neighbour-joining (above nodes) and maximumparsimony (below nodes) tree-making algorithms; only values $\geqslant 50 \%$ are shown. Filled circles indicate branches of the tree that were also recovered with the maximumlikelihood and maximum-parsimony algorithms; open circles indicate nodes that were also recovered in the tree generated with the maximum-parsimony algorithm only. Bar, 0.01 substitutions per nucleotide position. 
Table 1. Major fatty acids of strain $C L-33^{\top}$ and $E$. elysicola JCM $21568^{\top}$

Data are from this study; the two strains were grown on MA at $25{ }^{\circ} \mathrm{C}$ for 3 days. Values are percentages of the total fatty acids;,$-<0.5 \%$ or not detected.

\begin{tabular}{|lcc|}
\hline Fatty acid & CL-33 $^{\text {T }}$ & $\begin{array}{c}\text { E. elysicola } \\
\text { JCM 21568 }\end{array}$ \\
\hline $\mathrm{C}_{10: 0}$ 3-OH & 2.9 & 3.3 \\
$\mathrm{C}_{12: 0}$ 3-OH & - & 2.8 \\
$\mathrm{C}_{14: 0}$ & 8.5 & 6.1 \\
$\mathrm{C}_{16: 0}$ & 12.0 & 19.7 \\
$\mathrm{C}_{18: 0}$ & - & 2.1 \\
Summed feature 2* & 1.5 & 4.5 \\
Summed feature 3* & 39.6 & 50.0 \\
Summed feature $8^{*}$ & 32.8 & 9.9 \\
\hline
\end{tabular}

* Summed feature 2 comprised $\mathrm{C}_{14: 0} 3-\mathrm{OH}$ and/or iso- $\mathrm{C}_{16: 1} \mathrm{I}$; summed feature 3 comprised $\mathrm{C}_{16: 1} \omega 7 c$ and/or $\mathrm{C}_{16: 1} \omega 6 c$; summed feature 8 comprised $\mathrm{C}_{18: 1} \omega 7 c$ and/or $\mathrm{C}_{18: 1} \omega 6 c$.

for the assignment of strains to the same genomic species (Wayne et al., 1987).

Strain CL- $33^{\mathrm{T}}$ was examined for a broad range of phenotypic properties. Catalase, oxidase, DNase and lipase activity and hydrolysis of starch, casein and Tweens 20, 40, 60 and 80 were determined according to standard methods (Gerhardt et al., 1994; MacFaddin, 2000). The commercially available API 20NE (bioMérieux), API ZYM (bioMérieux) and MicroPlate GN2 (Biolog) microtest systems were used to determine the biochemical properties, enzyme activities and carbohydrate utilization pattern of strain CL-33 ${ }^{\mathrm{T}}$. API ZYM strips were read after $4 \mathrm{~h}$ incubation at $37^{\circ} \mathrm{C}$, whereas API 20NE and MicroPlate GN2 results were read after $72 \mathrm{~h}$ at $37{ }^{\circ} \mathrm{C}$. Bacterial inocula were suspended in saline solution $(3 \% \mathrm{NaCl}$, w/v) containing $10 \%(\mathrm{w} / \mathrm{v}) \mathrm{MB}$ for Biolog tests, whereas cell suspensions $(2 \% \mathrm{NaCl}, \mathrm{w} / \mathrm{v})$ were used for API $20 \mathrm{NE}$ tests (Thompson et al., 2006). API ZYM tests were performed according to the methods outlined by the manufacturer. Sensitivity to antibiotics was tested after spreading cells ( 0.5 McFarland standard) on MA and by using discs containing the following antibiotics: ampicillin $(10 \mu \mathrm{g})$, chloramphenicol $(30 \mu \mathrm{g})$, gentamicin $(10 \mu \mathrm{g})$, kanamycin $(30 \mu \mathrm{g})$, nalidixic acid $(30 \mu \mathrm{g})$, novobiocin $(30 \mu \mathrm{g})$, penicillin G $(10 \mu \mathrm{g})$, rifampicin $(5 \mu \mathrm{g})$, streptomycin $(10 \mu \mathrm{g})$, sulfamethoxazole plus trimethoprim $(23.75 / 1.25 \mu \mathrm{g})$ and tetracycline $(30 \mu \mathrm{g})$. The effects of antibiotics on cell growth were assessed after 3 days incubation, and susceptibility was scored on the basis of the distance from the edge of the clear zone to the disc. Cells were scored as susceptible if the distance was greater than $3 \mathrm{~mm}$, as moderately susceptible if the distance was $1-3 \mathrm{~mm}$ and as resistant if the distance was less than $1 \mathrm{~mm}$. Detailed results from the phenotypic and biochemical analyses of strain $\mathrm{CL}-33^{\mathrm{T}}$ are provided in Table 2 and in the species description. Distinctive characteristics of the genus Endozoicomonas are colony colour, maximum growth temperature, DNA G+C content and hydroxy fatty acid profile (Kurahashi \& Yokota, 2007); data for these characteristics for strain CL$33^{\mathrm{T}}$ were consistent with its assignment to the genus Endozoicomonas. It is therefore clear that strain CL-33 belongs to the genus Endozoicomonas. Phenotypic characteristics that differentiate strain CL-33 ${ }^{\mathrm{T}}$ from E. elysicola MKT $110^{\mathrm{T}}$ are presented in Table 2.

On the basis of $16 \mathrm{~S}$ rRNA gene sequence comparisons, strain CL-33 ${ }^{\mathrm{T}}$ occupies a distinct position within the genus Endozoicomonas. This genotypic distinctiveness was supported by the unique combination of chemotaxonomic characteristics (Tables 1 and 2) and biochemical traits (Table 2) for the strain. It is clear from the genotypic and phenotypic data presented that strain CL- $33^{T}$ represents a

Table 2. Differential genotypic and phenotypic characteristics between strain CL-33 ${ }^{\top}$ and E. elysicola MKT110 ${ }^{\top}$

Data for the isolation source and the DNA $G+C$ content of $E$. elysicola MKT $110^{\mathrm{T}}$ were taken from Kurahashi \& Yokota (2007); all other data were obtained in the present study. + , Positive reaction or growth; -, negative reaction or no growth; w, weakly positive reaction.

\begin{tabular}{|c|c|c|}
\hline Characteristic & CL-33 ${ }^{\mathrm{T}}$ & $\begin{array}{l}\text { E. elysicola } \\
\text { MKT110 }^{\mathrm{T}}\end{array}$ \\
\hline Isolation source & Coral & Sea slug \\
\hline Growth at $4{ }^{\circ} \mathrm{C}$ & - & + \\
\hline Oxidase activity & + & $\mathrm{W}$ \\
\hline Alkaline phosphatase & - & + \\
\hline C8 esterase & + & - \\
\hline$N$-Acetyl- $\beta$-glucosaminidase & - & + \\
\hline \multicolumn{3}{|l|}{ Oxidation (Biolog) of: } \\
\hline Dextrin & + & - \\
\hline Tween 40 & + & $\mathrm{w}$ \\
\hline Tween 80 & + & $\mathrm{w}$ \\
\hline Cellobiose & $\mathrm{w}$ & - \\
\hline L-Fucose & - & + \\
\hline Melibiose & $\mathrm{w}$ & - \\
\hline Pyruvic acid methyl ester & $\mathrm{w}$ & - \\
\hline Succinic acid monomethyl ester & $\mathrm{w}$ & - \\
\hline Acetic acid & $\mathrm{w}$ & - \\
\hline Citric acid & - & + \\
\hline Propionic acid & $\mathrm{w}$ & - \\
\hline Succinic acid & + & - \\
\hline Bromosuccinic acid & + & - \\
\hline L-Alaninamide & + & - \\
\hline L-Alanine & + & - \\
\hline L-Serine & + & - \\
\hline Inosine & $\mathrm{W}$ & - \\
\hline Uridine & + & - \\
\hline Thymidine & + & - \\
\hline Glycerol & + & - \\
\hline DNA G $+C$ content $(\mathrm{mol} \%)$ & 50.0 & 50.4 \\
\hline
\end{tabular}


novel species of the genus Endozoicomonas, for which the name Endozoicomonas montiporae sp. nov. is proposed.

\section{Description of Endozoicomonas montiporae sp. nov.}

Endozoicomonas montiporae (N.L. gen. fem. n. montiporae of Montipora, referring to the isolation of the type strain from a coral belonging to the genus Montipora).

Cells are Gram-negative, motile rods $(0.5-0.7 \mu \mathrm{m}$ in diameter and 1.0-3.0 $\mu \mathrm{m}$ long). Colonies on MA are beige, circular and convex with entire edges. Colonies are approximately $1.0-2.0 \mathrm{~mm}$ in diameter on MA after $72 \mathrm{~h}$ incubation at $25{ }^{\circ} \mathrm{C}$. Growth occurs at $15-35{ }^{\circ} \mathrm{C}$, at pH $6-$ 10 and in the presence of $1-3 \% \mathrm{NaCl}$. Optimum growth occurs at $25^{\circ} \mathrm{C}$, at $\mathrm{pH} 8.0$ and in the presence of $2-3 \%$ $\mathrm{NaCl}$. Cells are aerobic. No accumulation of poly- $\beta$ hydroxybutyrate granules. Positive for oxidase, catalase, DNase and hydrolysis of Tween 20. Negative for lipase (corn oil) and hydrolysis of casein, starch and Tweens 40, 60 and 80. Positive for the following: nitrate reduction, aesculin hydrolysis, alkaline phosphatase, C4 esterase, C8 esterase, leucine arylamidase, acid phosphatase, naphtholAS-BI-phosphohydrolase and $\alpha$-glucosidase. Negative for the following: indole production, glucose fermentation, arginine dihydrolase, urease, gelatin hydrolysis, C14 lipase, valine arylamidase, cystine arylamidase, trypsin, $\alpha$-chymotrypsin, $\alpha$-galactosidase, $\beta$-galactosidase, $\beta$-glucuronidase, $\beta$-glucosidase, $N$-acetyl- $\beta$-glucosaminidase, $\alpha$-mannosidase and $\alpha$-fucosidase. The following carbon substrates (Biolog GN2) are oxidized: dextrin, Tweens 40 and 80, $N$-acetyl-Dglucosamine, cellobiose, D-galactose, $\alpha$-D-glucose, maltose, melibiose, methyl pyruvate, monomethyl succinate, acetic acid, $\alpha$-ketobutyric acid, $\alpha$-ketoglutaric acid, propionic acid, succinic acid, bromosuccinic acid, L-alaninamide, Lalanine, inosine, uridine, thymidine and glycerol. Does not oxidize $\alpha$-cyclodextrin, glycogen, $N$-acetyl-D-galactosamine, adonitol, L-arabinose, D-arabitol, i-erythritol, Dfructose, L-fucose, gentiobiose, myo-inositol, lactulose, Dmannitol, D-mannose, methyl $\beta$-D-glucoside, D-psicose, raffinose, L-rhamnose, D-sorbitol, sucrose, trehalose, turanose, xylitol, cis-aconitic acid, citric acid, formic acid, Dgalactonic acid lactone, D-galacturonic acid, D-gluconic acid, D-glucosaminic acid, D-glucuronic acid, $\alpha$-hydroxybutyric acid, $\beta$-hydroxybutyric acid, $\gamma$-hydroxybutyric acid, $p$-hydroxyphenylacetic acid, itaconic acid, $\alpha$-ketovaleric acid, DL-lactic acid, malonic acid, quinic acid, D-saccharic acid, sebacic acid, succinamic acid, glucuronamide, D-alanine, L-alanyl glycine, L-asparagine, L-aspartic acid, L-glutamic acid, glycyl L-aspartic acid, glycyl L-glutamic acid, L-histidine, hydroxy-L-proline, L-leucine, L-ornithine, Lphenylalanine, L-proline, L-pyroglutamic acid, D-serine, Lthreonine, DL-carnitine, $\gamma$-aminobutyric acid, urocanic acid, phenylethylamine, putrescine, 2-aminoethanol, 2,3-butanediol, DL- $\alpha$-glycerol phosphate, $\alpha$-D-glucose 1-phosphate or Dglucose 6-phosphate. Sensitive to ampicillin, chloramphenicol, gentamicin, kanamycin, nalidixic acid, novobiocin, penicillin G, rifampicin, streptomycin, sulfamethoxazole plus trimethoprim and tetracycline. The predominant fatty acids are summed feature $3\left(\mathrm{C}_{16: 1} \omega 7 c\right.$ and/or $\left.\mathrm{C}_{16: 1} \omega 6 c\right)$, summed feature $8\left(\mathrm{C}_{18: 1} \omega 7 c\right.$ and/or $\left.\mathrm{C}_{18: 1} \omega 6 c\right)$, $\mathrm{C}_{16: 0}$ and $\mathrm{C}_{14: 0}$. The major respiratory quinone is ubiquinone 9 and the DNA $\mathrm{G}+\mathrm{C}$ content of the type strain is $50.0 \mathrm{~mol} \%$.

The type strain, CL-33 ${ }^{\mathrm{T}}\left(=\mathrm{LMG} 24815^{\mathrm{T}}=\mathrm{BCRC} 17933^{\mathrm{T}}\right)$, was isolated from the encrusting pore coral Montipora aequituberculata collected from seawater off southern Taiwan.

\section{Acknowledgements}

This study was funded by grants from the Academia Sinica (Thematic Grant 20082010), Taipei, Taiwan, Republic of China.

\section{References}

Chen, W. M., Laevens, S., Lee, T. M., Coenye, T., De Vos, P., Mergeay, M. \& Vandamme, P. (2001). Ralstonia taiwanensis sp. nov., isolated from root nodules of Mimosa species and sputum of a cystic fibrosis patient. Int J Syst Evol Microbiol 51, 1729-1735.

Chun, J., Lee, J.-H., Jung, Y., Kim, M., Kim, S., Kim, B. K. \& Lim, Y. W. (2007). EzTaxon: a web-based tool for the identification of prokaryotes based on $16 \mathrm{~S}$ ribosomal RNA gene sequences. Int J Syst Evol Microbiol 57, 2259-2261.

Collins, M. D. (1985). Analysis of isoprenoid quinones. Methods Microbiol 18, 329-366.

Ezaki, T., Hashimoto, Y. \& Yabuuchi, E. (1989). Fluorometric deoxyribonucleic acid-deoxyribonucleic acid hybridization in microdilution wells as an alternative to membrane filter hybridization in which radioisotopes are used to determine genetic relatedness among bacterial strains. Int J Syst Bacteriol 39, 224-229.

Felsenstein, J. (1981). Evolutionary trees from DNA sequences: a maximum likelihood approach. J Mol Evol 17, 368-376.

GCG (1995). Wisconsin Package Version 8.1 Program Manual. Madison, WI: Genetics Computer Group.

Gerhardt, P., Murray, R. G. E., Wood, W. A. \& Krieg, N. R. (editors) (1994). Methods for General and Molecular Bacteriology. Washington, DC: American Society for Microbiology.

Hall, T. A. (1999). BioEdit: a user-friendly biological sequence alignment editor and analysis program for Windows 95/98/NT. Nucleic Acids Symp Ser 41, 95-98.

Jukes, T. H. \& Cantor, C. R. (1969). Evolution of protein molecules. In Mammalian Protein Metabolism, vol. 3, pp. 21-132. Edited by H. N. Munro. New York: Academic Press.

Kluge, A. G. \& Farris, J. S. (1969). Quantitative phyletics and the evolution of anurans. Syst Zool 18, 1-32.

Kumar, S., Tamura, K. \& Nei, M. (2004). MEGA3: integrated software for molecular evolutionary genetics analysis and sequence alignment. Brief Bioinform 5, 150-163.

Kurahashi, M. \& Yokota, A. (2007). Endozoicomonas elysicola gen. nov., sp. nov., a $\gamma$-proteobacterium isolated from the sea slug Elysia ornata. Syst Appl Microbiol 30, 202-206.

MacFaddin, J. F. (2000). Biochemical Tests for the Identification of Medical Bacteria, 3rd edn. Baltimore: Williams \& Wilkins.

Maidak, B. L., Cole, J. R., Lilburn, T. G., Parker, C. T., Jr, Saxman, P. R., Farris, R. J., Garrity, G. M., Olsen, G. J., Schmidt, T. M. \& Tiedje, J. M. 
(2001). The RDP-II (Ribosomal Database Project). Nucleic Acids Res 29, 173-174.

Mesbah, M., Premachandran, U. \& Whitman, W. B. (1989). Precise measurement of the $\mathrm{G}+\mathrm{C}$ content of deoxyribonucleic acid by highperformance liquid chromatography. Int J Syst Bacteriol 39, 159167.

Minnikin, D. E., O'Donnell, A. G., Goodfellow, M., Alderson, G., Athalye, M., Schaal, A. \& Parlett, J. H. (1984). An integrated procedure for the extraction of bacterial isoprenoid quinones and polar lipids. J Microbiol Methods 2, 233-241.

Powers, E. M. (1995). Efficacy of the Ryu nonstaining KOH technique for rapidly determining gram reactions of food-borne and waterborne bacteria and yeasts. Appl Environ Microbiol 61, 3756-3758.
Saitou, N. \& Nei, M. (1987). The neighbor-joining method: a new method for reconstructing phylogenetic trees. Mol Biol Evol 4, 406-425.

Sasser, M. (1990). Identification of bacteria by gas chromatography of cellular fatty acids, MIDI Technical Note 101. Newark, DE: MIDI Inc.

Thompson, F. L., Barash, Y., Sawabe, T., Sharon, G., Swings, J. \& Rosenberg, E. (2006). Thalassomonas loyana sp. nov., a causative agent of the white plague-like disease of corals on the Eilat coral reef. Int J Syst Evol Microbiol 56, 365-368.

Wayne, L. G., Brenner, D. J., Colwell, R. R., Grimont, P. A. D., Kandler, O., Krichevsky, M. I., Moore, L. H., Moore, W. E. C., Murray, R. G. E. \& other authors (1987). International Committee on Systematic Bacteriology. Report of the ad hoc committee on reconciliation of approaches to bacterial systematics. Int J Syst Bacteriol 37, 463-464. 